\title{
Groundwater Quality Assessment of Abandoned Dumpsite in Osogbo Suburb, Nigeria: Hydrogeological and Geophysical Condition Six Years after Initial Study
}

\author{
${ }^{* 1}$ OJO, AO, ${ }^{1}$ OYELAMI AC, ${ }^{2}$ BABAFEMI, EM \\ ${ }^{* 1}$ Department of Geological Sciences, Osun State University, Osogbo, Nigeria \\ ${ }^{2}$ Geobabs Integrated Services, Lagos, Nigeria \\ *Corresponding Author Email: adeolu.ojo@ uniosun.edu.ng; Tel: +2348035626912 \\ Other Authors Email: adebayo.oyelami@uniosun.edu.com; emmanuelmuyiwa32@gmail.com
}

\begin{abstract}
In this paper, we describe the result of a recent hydrogeological and geophysical investigation carried out within and around Aduramigba - Onibu-Eja Estate dumpsite with the aim of detecting evidence of contamination as well as depths to contamination of the groundwater after a previous study six years ago. Twenty water samples from shallow water wells and boreholes were analyzed for their physico-chemical constituents while five vertical electrical soundings and five electromagnetic ground penetrating radar surveys were conducted. The result shows high concentrations of anions of nitrates $\left(\mathrm{NO}_{3}^{-}\right)$, bicarbonates $\left(\mathrm{HCO}_{3}{ }^{-}\right)$, chloride $\left(\mathrm{Cl}^{-}\right)$and sulphate $\left(\mathrm{SO}^{2-}\right)$ with values of 73.97 $\mathrm{mg} / \mathrm{l}, 91.5 \mathrm{mg} / \mathrm{l}, 331.2 \mathrm{mg} / \mathrm{l}, 222.4 \mathrm{mg} / \mathrm{l}$ respectively, cations values of $\mathrm{Mg}^{2+}, \mathrm{Fe}^{2+}, \mathrm{Na}^{+}$, and $\mathrm{K}^{+}$having value of 25.44 $\mathrm{mg} / 1,6.23 \mathrm{mg} / \mathrm{l}, 37.31 \mathrm{mg} / \mathrm{l}$ and $35.41 \mathrm{mg} / \mathrm{l}$, respectively, which were far above the World Health Organization (WHO) and Nigeria Drinking Water Quality Standard (NDWS). Heavy metal components such as Lead, Zinc, Copper and Nickel were also observed to be on the high side, having been contributed from effluents from rust metallic materials cum chemicals dumped within the dumpsite. Detailed geophysical study reveal the depth to contamination at between 4.1 meters in VES 3 to 5.9 meters in VES 2 with resistivity as low as $5.12 \Omega \mathrm{m}$ in VES 2 to $7.12 \Omega \mathrm{m}$ in VES 3 while ground penetrating radar (GPR) revealed that the leachate has permeated to a depth of $3.5-5.25$ meters in traverse 4 and $4.0-$ 6.0 meters in traverse 3 which correspond to the depth to unconfined aquifer within the dumpsite. The study conclude that this would pose a greater threat to residents living in this vicinity and as such, this might have contributed to the closure of the dumpsite.
\end{abstract}

\section{DOI: https://dx.doi.org/10.4314/jasem.v25i7.17}

Copyright: Copyright $(0) 2021$ Ojo et al. This is an open access article distributed under the Creative Commons Attribution License (CCL), which permits unrestricted use, distribution, and reproduction in any medium, provided the original work is properly cited.

Dates: Received: 10 May 2021; Revised: 28 June 2021; Accepted: 01 July 2021

Keywords: Cation; Contamination; Dumpsite; Onibu-Eja; Radar; Penetrating

This work is a follow-up to an initial work carried out six years ago by Oyelami et al., (2013) and Ojo et al., (2014) on the effect of this dumpsite on the groundwater in Onibu-Eja communities and Aduramigba estate, Ido-Osun, suburb of Osogbo, South western Nigeria. Another series of investigations were conducted in January, 2019 to study present situation six years after the earlier study. It was reported that the dumpsite has been closed down in response to complaints by residents in the area about the groundwater wells and shallow boreholes that waters in them exhibit characteristic change in taste, colour and odour. The study was carried out to ascertain the depth to pollution and extent of pollution of the groundwater in the study area. The dumpsite was of significance because it serves as the only major dumpsite that has been in use in Osogbo metropolis and also serves the entire Osogbo town and immediate environment. Past studies by Oyelami et al., (2013) reported that the groundwater quality in the area was well protected having found to contain cations concentration, anion concentration as well as physico- chemical parameters that fell below the acceptable World Health Organization (WHO) standard as well as the Nigeria drinking water standard. Ojo et. al., (2014) also carried out geophysical investigation within the same dumpsite in order to determine the geoelectric parameters in relation to the lithologic identity and subsurface characteristics of the dumpsite environment. Their research confirmed that the dumpsite is underlain by a 0.3 to $1.1 \mathrm{~m}$ thick lateritic topsoil having resistivity values between $104 \Omega \mathrm{m}$ and $437 \Omega \mathrm{m}$ which serves as a hard pan over a 7 to $13 \mathrm{~m}$ thick predominantly clayey/weathered layer interval with a resistivity value between 35 to $80 \Omega \mathrm{m}$. It was concluded that these two layers, although relatively thin, serve to prevent the leachate from percolating into the groundwater in the study area. Situation report six years after initial investigation indicated that there has been evidence of contamination of the groundwater. World over, change in groundwater chemistry (and ultimately quality) have contributed to a great number of health issues. Prasad, (1984) as well as Olajire and Imeokparia, (2001) observed that in 
third world countries, $80 \%$ of all diseases are directly related to drinking water of poor quality and unhygienic conditions, some of which include typhoid and paratyphoid fevers (Salmonellosis), cholera, bacillary dysentery (Shigellosis), infectious hepatitis, dracontiasis, schistosomiasis, to mention a few (Udoessien 2000: Ukpong and Okon (2013). Owamah et al. (2013) and Shittu et. al. (2009) observed that quite a number of rural settlements in Nigeria have been perpetually dependent on groundwater wells for their consumption due to the fact that they do not have access to potable water. During the vertical percolation process (with rain water), the water leaches both organic and inorganic constituents from refuse and becomes part of the groundwater flow system when they get to the water level (Langer, 1998). Monitoring wells give point measurements whereas leachate plumes tend to migrate along preferential pathways, determined by subsurface heterogeneity (Zume, et al. 2006). Therefore, even with a network of closely spaced monitoring wells, the risk that some contaminants could go undetected remains high. For these reasons, there is the need to integrate two or more techniques in this study, hence the application of non-invasive and relatively inexpensive geophysical techniques such as electromagnetic ground penetrating radar technique and the vertical electrical sounding technique as means for mapping the occurrence of pollution. These geophysical methods have found use in contaminant waste detection and for evaluation of possible leachate flow after dumping of waste because they generate nearly continuous image of the subsurface that can significantly reduce the risk of undetected contaminants (Zume et al., 2006; Olorunfemi and Mesida, 1987). This report therefore presents the application of the ground penetrating radar and the vertical electrical sounding technique of electrical resistivity method with analysis of selected groundwater samples from groundwater wells and shallow boreholes in the vicinity of the dumpsite in the delineation of pollution plume, locate lithologic layers and as well as possible leachate flow in the study area. Both geophysical methods are fast and cost effective. It is expected that conclusion from the use of a combination of these hydrogeological and geophysical procedures would provide detailed information about the quality status of groundwater in the study area. The outcome of these investigations can help in appropriate decision-making on remediation methods to adopt.

\section{MATERIALS AND METHODS}

The study area: Aduramigba and Onibu-Eja communities, as described by Ojo et al., (2014) and Oyelami et al., (2013) is located on the outskirt of Osogbo, along Iwo road. Figure 1.0. It lies between longitude $07^{\circ} 46^{\prime} 35^{\prime \prime} \mathrm{N}-07^{\circ} 47^{\prime} 45^{\prime \prime} \mathrm{N}$ and latitude $004^{\circ} 29^{\prime} 14^{\prime \prime} \mathrm{E}-004^{\circ} 30^{\prime} 28^{\prime \prime} \mathrm{E}$. The area is part of IdoOsun local government area of the state. Due to intensive and rapid urbanization of Osogbo, the State capital, this has made civil servants as well as small scale industry owners to begin to move to the outskirt of the town, especially the study area. Since then, there has been mass movement of people to this area. The dumpsite has been in use for about eight years after moving from a previous site. It is the only active dumpsite in the study. It serves for all dumps from within Osogbo as well as the neighboring suburbs. Geologically, the study area falls within the Basement complex of Southwestern Nigeria.

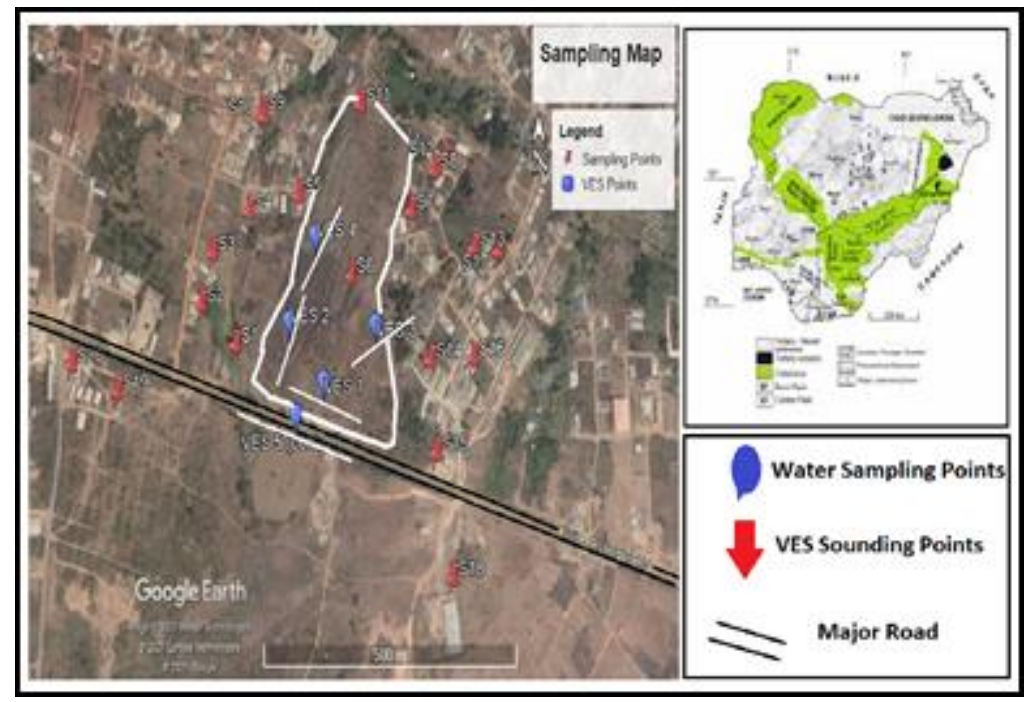

Fig 1: Location Map of the Dumpsite showing the Sampling Points and VES Sounding Points 
Twenty (20) water wells and boreholes were sampled around the vicinity of the dumpsite. The coordinates of each sampling point were pre-defined using the global positioning system (GPS). The electrical conductivity $\mathrm{EC}, \mathrm{pH}$, and temperature were taken insitu with the aid of multi parameter $\mathrm{EC} / \mathrm{pH}$ meter. Other parameters such as total dissolved solid (TDS), TSS, turbidity, odour were also measured. Water samples from these wells were taken to the laboratory immediately for analysis of the cation, anion and the heavy metals using Atomic Absorption Spectrophotometer, Iron Chromatographic method. Titrimetric method was used for $\mathrm{SO}_{4}{ }^{2-}$ and $\mathrm{HCO}_{3}{ }^{-}$. In this study, we ensured prescription of APHA 2005 mode of analysis. Five anion nitrate $\left(\mathrm{NO}_{3}{ }^{-}\right)$, carbonate $\left(\mathrm{CO}_{3}{ }^{2-}\right)$ bicarbonate $\left(\mathrm{HCO}_{3}{ }^{-}\right)$, chloride $\left(\mathrm{Cl}^{-}\right)$and sulphate $\left(\mathrm{SO}_{4}{ }^{2-}\right)$. Cations and heavy metals analyzed for includes: Cobalt, Chromium, Cadmium Calcium, Magnesium, Potassium and Sodium, Manganese, Iron, Copper, Zinc, Lead and Nickel. The results of the analysis were compared with the Nigerian Standard Drinking Water Quality and World Health Organization (WHO). Four vertical electric soundings (VES) survey were carried out within and around the study area while one carried out outside the dumpsite to serve for parametric control of the investigation. The results were interpreted using the DC Inversion iterative softwares. Four GPR profiles were established within the dumpsite and a control outside the dumpsite. GPR data were collected using the monostatic high frequency electromagnetic GPR machine Model GSSI SIR 1000. Geologic scan parameters, typical of environmental contamination study was pre-configured into the TerraSIR mode. The preset includes $\Delta \mathrm{T}$ rate (100), rate (80), range (maximum for antenna), gauge (5 Auto.), survey and wheel calibration (1024) sample per scan, Soil type 2 (damp sand/dry silt/ damp grade) and dielectric of 8 . The GPR data were collected, processed and interpreted using the processing and interpretative software. Results from these two approached were integrated to provide a detailed view of the extent of contamination. Three pits were dug in the vicinity of each of the GPR profile. This was done with the aim of correlation with the results. Three pits were dug within the study area while one dug outside the dumpsite.

\section{RESULTS AND DISCUSSION}

Table 1 shows the result of the physicochemical analysis of the water samples around the dumpsite while table 2, the percentage contribution of heavy metals, cations and anion in the contamination. Table 3.0 represents the summary of the interpreted VES data. Figure $2 \mathrm{a}$ and $2 \mathrm{~b}$ represents the percentages of heavy metals, cations and anion. However, Figure 3,
4, 5 and 7 represent geoelectric columns integrated with the GPR radargram. Figure 8 represent the geoelectric section of the study area showing the VES points relative to elevation. Interpretation of the results of groundwater analysis showed that the concentration of anions as well as heavy metals have increased considerably from the earlier values reported by Oyelami et. al., (2013). Concentrations of $\mathrm{Ca}^{2+}$ fall within acceptable limit having all the samples in the study area with values less than the $75 \mathrm{mg} / \mathrm{l}$ and 150 $\mathrm{mg} / \mathrm{l}$ of the WHO standard and the Nigeria drinking water standard. Likewise, the values obtained for $\mathrm{HCO}_{3}{ }^{-}$ion. This confirms that the groundwater does not WHO (2016) observed that the total dissolved solid (TDS) are usually contributed into groundwater from inorganic bicarbonates, chlorides and sulfates salts of potassium, sodium, calcium, magnesium, as well as small amounts of bio-matters dissolved in water. These have found their roots from natural sources, sewage, and surface runoff in urban settlements as well as wastewater effluents from industries. The TDS values observed from the analysis fall within acceptable standard. This is evident from values obtained from cations of $\mathrm{Na}^{+}, \mathrm{Ca}^{2+}, \mathrm{Mg}^{2+}$, and $\mathrm{K}^{+}$. However, this is not the case with heavy metals concentrations in groundwater. More than $50 \%$ of the groundwater samples studied experience $\mathrm{Cu}^{2+}, \mathrm{Pb}^{2+}$, $\mathrm{Ni}^{2+}, \mathrm{Fe}^{2+}$ and $\mathrm{Mn}^{2+}$ pollution with little or no $\mathrm{Zn}^{2+}$, $\mathrm{Cd}^{+}$or $\mathrm{Cr}^{2+}$ pollution. Concentration of $\mathrm{Cu}^{2+}$ in the sampled groundwater range from $1.1 \mathrm{mg} / \mathrm{l}$ in sampled well 4 to $4.3 \mathrm{mg} / \mathrm{l}$ in sampled well 13 . This must have been contributed from dumps of metallic materials which have been buried within the dumpsite over a period of time. The presence of $\mathrm{Cu}^{2+}$ in groundwater is believed to trigger up gastrointestinal disorder in humans while excessive $\mathrm{Pb}^{2+}$ do serve as precursors to cancer, interact with Vitamin D metabolism, affect mental development in children and do cause extensive damage to the central and peripheral nervous systems of humans. Likewise, almost $80 \%$ of anion pollution has been contributed by $\mathrm{NO}_{3}{ }^{-}$while $10 \%$ has been contributed by $\mathrm{SO}_{4}{ }^{2-}$ (Figure 2). This is not unconnected with remains of plants, animal as well as domestic wastes dumped into the study area. For the leachate to have moved into the acquiferous layer under a period of six years is a pointer to the fact that there might have occurred occurrence of secondary porosity due to faulting and fracturing within the area coupled with heavy wastes brought from small scale industries that generates wastes from other parts of the city. From the investigation, the results showed that most of the VES obtained from the study area reveal a typical KHA curve except VES 2 which exhibit HA configuration. Generally, resistivities within the study area are on the lowest side due to the profound effect of the contamination within the dumpsite. 
Table 1: Table showing Results of Groundwater Quality Analysis from Recent Study

\begin{tabular}{|c|c|c|c|c|c|c|c|c|c|c|c|c|c|c|c|c|c|c|c|c|}
\hline & \multicolumn{4}{|c|}{ Cations } & \multicolumn{8}{|c|}{ Heavy Metals } & \multicolumn{5}{|c|}{ Anions } & \multicolumn{3}{|c|}{ Physical Parameters } \\
\hline & $\begin{array}{l}\mathrm{mg} / \mathrm{l} \\
\mathrm{Ca}^{2+}\end{array}$ & $\begin{array}{l}\mathbf{m g} / \mathbf{l} \\
\mathbf{M g}^{2+}\end{array}$ & $\begin{array}{l}\mathrm{mg} / \mathrm{l} \\
\mathrm{K}^{+}\end{array}$ & $\begin{array}{l}\mathbf{m g / l} / \mathbf{l} \\
\mathrm{Na}^{+}\end{array}$ & $\begin{array}{l}\mathrm{mg} / \mathrm{l} \\
\mathrm{Mn}\end{array}$ & $\begin{array}{l}\mathrm{mg} / \mathrm{l} \\
\mathrm{Fe}\end{array}$ & $\begin{array}{l}\mathrm{mg} / \mathrm{l} \\
\mathrm{Cu}\end{array}$ & $\begin{array}{l}\mathrm{mg} / \mathrm{l} \\
\mathrm{Zn}\end{array}$ & $\begin{array}{l}\mathrm{mg} / \mathrm{l} \\
\mathrm{Pb}\end{array}$ & $\begin{array}{l}\mathbf{m g} / \mathbf{l} \\
\mathrm{Cr}\end{array}$ & $\begin{array}{l}\mathbf{m g} / \mathbf{l} \\
\mathbf{C d}\end{array}$ & $\begin{array}{l}\mathrm{mg} / \mathrm{l} \\
\mathrm{Ni}\end{array}$ & $\begin{array}{l}\mathrm{mg} / \mathrm{l} \\
\mathrm{NO}_{3}^{-}\end{array}$ & $\begin{array}{l}\mathrm{mg} / \mathrm{l} \\
\mathrm{HCO}_{3}\end{array}$ & $\begin{array}{l}\mathbf{m g} / \mathbf{l} \\
\mathrm{Cl}^{-}\end{array}$ & $\begin{array}{l}\mathrm{mg} / \mathrm{l} \\
\mathrm{SO}_{4}{ }^{2-}\end{array}$ & $\begin{array}{l}\mathbf{E c} \\
\mu \mathrm{S} / \mathrm{cm}\end{array}$ & $\mathrm{pH}$ & $\begin{array}{l}\text { Temp } \\
{ }^{\circ} \mathrm{C} \\
\end{array}$ & TDS \\
\hline W1 & 20.11 & 3.59 & 2.67 & 4.12 & 0.04 & 0.02 & 2.1 & 0.004 & 0 & 0 & 0 & $\mathrm{Ni}$ & 64.63 & 61 & 259.2 & 123.5 & 155 & 10.2 & 28.1 & 116.25 \\
\hline W 2 & 15.62 & 6.6 & 1.59 & 5.04 & 0.05 & 0.41 & 4.4 & 0.001 & 0.46 & 0 & 0 & 0 & 57.09 & 61 & 86.4 & 0.493 & 147 & 9.4 & 27.1 & 110.25 \\
\hline W3 & 6.18 & 27.7 & 1.73 & 2.89 & 0.43 & 5.95 & 1.3 & 0.003 & 0.52 & 0 & 0 & 0.33 & 73.97 & 45.75 & 200.8 & 186.6 & 335 & 8.8 & 26.2 & 251.25 \\
\hline W4 & 25.45 & 16.95 & 0.81 & 2.56 & 0.6 & 0.01 & 1.1 & 0 & 0.43 & 0 & 0 & 0.51 & 58.7 & 61 & 236 & 149.3 & 256 & 9.3 & 25.6 & 192 \\
\hline W5 & 17.94 & 12.35 & 0.87 & 1.33 & 0.02 & 0.02 & 3.4 & 0.05 & 0 & 0 & 0 & 0.48 & 56.76 & 61 & 115.2 & 135.9 & 249 & 8.5 & 26.5 & 186.75 \\
\hline W6 & 19.51 & 7.83 & 1.17 & 9.97 & 0 & 0.01 & 2.2 & 0 & 0 & 0 & 0 & 0 & 57 & 30 & 86.4 & 222.4 & 221 & 9.3 & 26 & 165.75 \\
\hline W7 & 6.97 & 4.34 & 0.92 & 7.71 & 0.3 & 2.4 & 0.45 & 0 & 0.34 & 0 & 0 & 0 & 57.48 & 47.75 & 194.4 & 185.5 & 126 & 9.5 & 22.7 & 94.5 \\
\hline W8 & 38.22 & 3.21 & 2.87 & 4.32 & 0.34 & 1.8 & 0.01 & 0.027 & 0.67 & 0 & 0 & 0.68 & 50.39 & 30 & 93.6 & 111.1 & 226 & 9.1 & 24.9 & 169.5 \\
\hline W9 & 46.5 & 12.5 & 3.69 & 20.12 & 0.44 & 1.5 & 0.02 & 0.01 & 1.4 & 0 & 0 & 0.91 & 61.14 & 45.8 & 93.6 & 271.7 & 357 & 9.2 & 24.2 & 267.75 \\
\hline W10 & 39.3 & 30.8 & 5.75 & 5.54 & 0.56 & 0.55 & 0.55 & 0 & 0.71 & 0 & 0 & 1.2 & 0.36 & 45.8 & 136 & 7.43 & 411 & 9.0 & 26.1 & 308.25 \\
\hline W11 & 38.7 & 26.7 & 4.07 & 6.35 & 0.02 & 0.08 & 0 & 0 & 0 & 0 & 0 & 0.5 & 61.18 & 30 & 100 & 112 & 389 & 9.5 & 27.1 & 291.75 \\
\hline W12 & 46.9 & 32.9 & 3.75 & 4.11 & 0.01 & 0.12 & 0 & 0 & 0 & 0 & 0 & 0 & 0.96 & 30 & 115.2 & 37 & 459 & 9.5 & 27.1 & 344.25 \\
\hline W13 & 2.53 & 10.5 & 1.56 & 6.12 & 0.51 & 2.9 & 4.3 & 0 & 0.33 & 0 & 0 & 0 & 0.75 & 61 & 244 & N.D & 117 & 9.5 & 25.3 & 87.75 \\
\hline W14 & 1.49 & 3.02 & 0.97 & 8.07 & 0 & 0.13 & 0 & 0 & 0 & 0 & 0 & 0.71 & 60.96 & 61 & 208 & 24.6 & 82 & 8.4 & 26.4 & 61.5 \\
\hline W15 & 33.0 & 19.05 & 5.46 & 14.72 & 0 & 1.8 & 2.5 & 0 & 0.54 & 0 & 0 & 0 & 1.07 & 61 & 122 & ND & 366 & 8.7 & 26.0 & 274.5 \\
\hline W16 & 22.1 & 3.72 & 4.28 & 8.12 & 0.42 & 1.2 & 3 & 0 & 0.32 & 0 & 0 & 0.66 & 51.25 & 91.5 & 100.8 & 19.9 & 187 & 9.5 & 27.4 & 140.25 \\
\hline W17 & 4.58 & 6.23 & 4.26 & 9.56 & 0.44 & 2.7 & 4 & 0 & 0.44 & 0 & 0 & 0.45 & 51.42 & 91.5 & 144 & 15 & 144 & 9.5 & 23.5 & 108 \\
\hline W18 & 25.5 & 6.6 & 7.54 & 9.44 & 0.02 & 0.07 & 2.4 & 0 & 0 & 0 & 0 & 0.41 & 12.5 & 30 & 331.2 & ND & 259 & 7.8 & 27.1 & 194.25 \\
\hline W19 & 17.7 & 2.95 & 8.56 & 3.21 & 0.09 & 0.14 & 0 & 0 & 0 & 0 & 0 & 0 & 69.12 & 30 & 223.2 & 104 & 127 & 7.9 & 27.6 & 95.25 \\
\hline W20 & 43.7 & 4.3 & 6.3 & 6.1 & 0.05 & 0.21 & 3.2 & 0.04 & 0 & 0 & 0 & 0 & 69.00 & 30 & 158.4 & ND & 279 & 9.1 & 27.4 & 209.25 \\
\hline WHO 2016 & 75 & 50 & 10 & 200 & 0.05 & $0.3-1.0$ & 2 & 0.05 & 0.1 & 0.5 & 0.003 & 0 & $50-100$ & $30-400$ & $200-600$ & $200-400$ & $1000 \mathrm{~m}$ & $6.5-8.5$ & AMB & 500 \\
\hline NDWS & 150 & 0.2 & NS & 200 & 0.2 & 0.3 & 1.0 & 3.0 & 0.01 & 0.5 & 0.003 & 0.02 & 50 & 150 & 250 & 100 & 1000 & $6.5-8.5$ & AMB & 500 \\
\hline
\end{tabular}

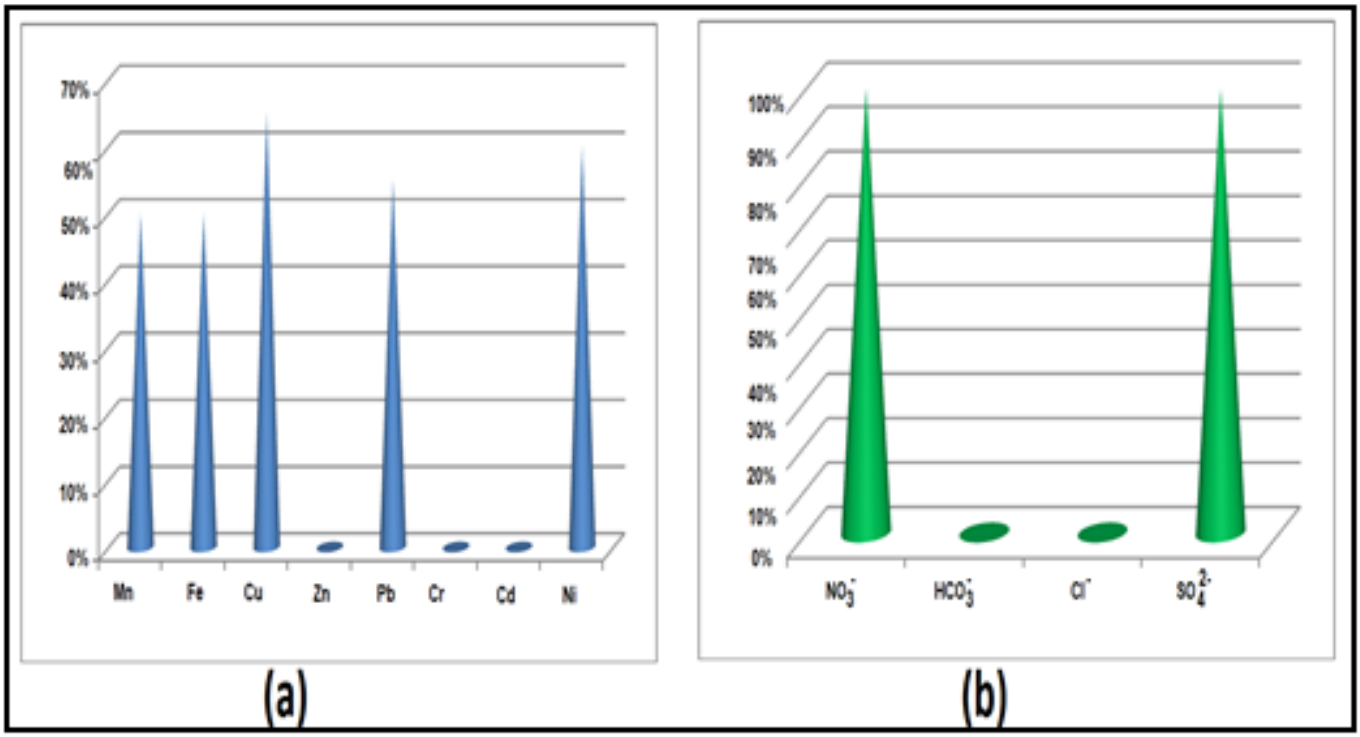

Fig 2a and b: showing the Percentage of Cation/Heavy Metals pollutants in the Groundwater 
The resistivity measured by the instrument was observed to be lower than the range of resistivity of the soil material. It ranges from as low as $5.1 \Omega \mathrm{m}$ in VES 2 to $40 \Omega \mathrm{m}$ in VES 3 - typical resistivity for highly conductive contamination materials. The topsoil varies in thickness from as low $0.41 \mathrm{~m}$ in VES 3 to as high as $2.07 \mathrm{~m}$ in VES 2 .

Table 2: Percentage Contribution of Cation/Heavy metals and

\begin{tabular}{ll}
\multicolumn{2}{c}{ Anion in Groundwater Pollution } \\
\hline Cation/Anion & $\%$ Contribution \\
\hline $\mathrm{Mn}^{2+}$ & $50 \%$ \\
$\mathrm{Fe}^{2+}$ & $50 \%$ \\
$\mathrm{Cu}^{2+}$ & $65 \%$ \\
$\mathrm{Zn}^{2+}$ & $0 \%$ \\
$\mathrm{~Pb}^{2+}$ & $55 \%$ \\
$\mathrm{Cr}^{2+}$ & $0 \%$ \\
$\mathrm{Cd}^{2+}$ & $0 \%$ \\
$\mathrm{Ni}^{2+}$ & $60 \%$ \\
$\mathrm{NOr}^{-}$ & $80 \%$ \\
$\mathrm{HCO}^{-}$ & $0 \%$ \\
$\mathrm{Cl}^{-}$ & $0 \%$ \\
$\mathrm{SO}_{4}{ }^{2-}$ & $10 \%$ \\
\hline
\end{tabular}

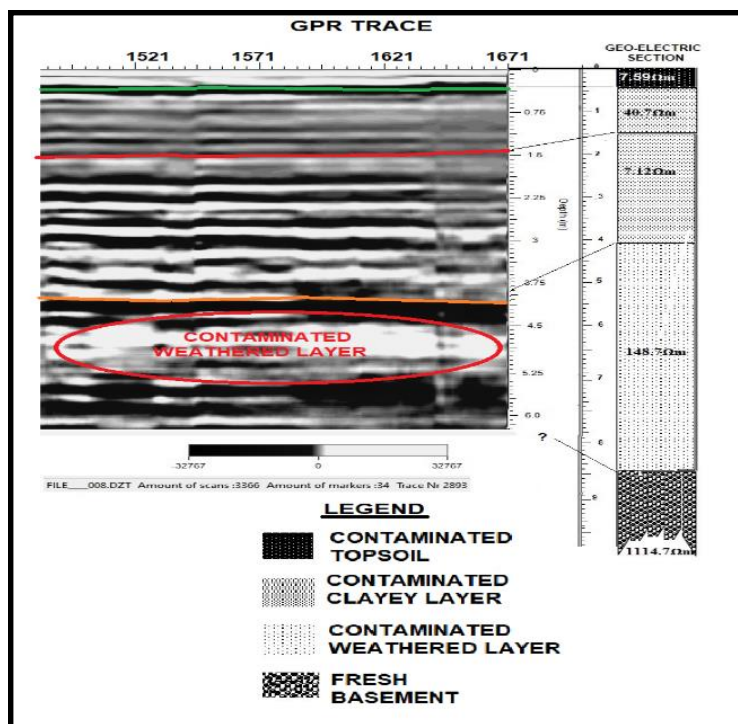

Fig 5: Geo-section - GPR trace through VES 3

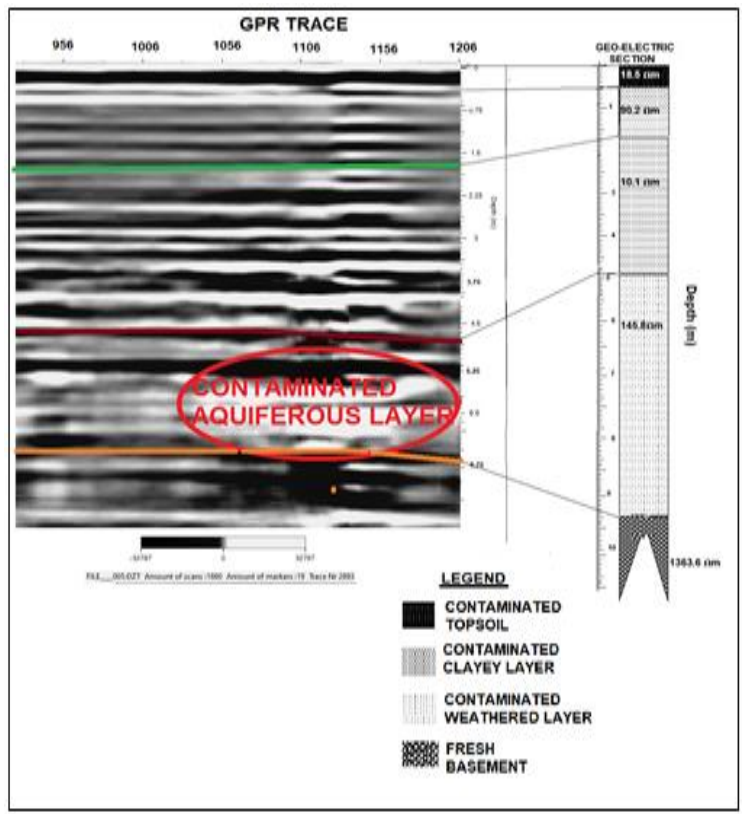

Fig 3: Geo-section - GPR trace through VES 1

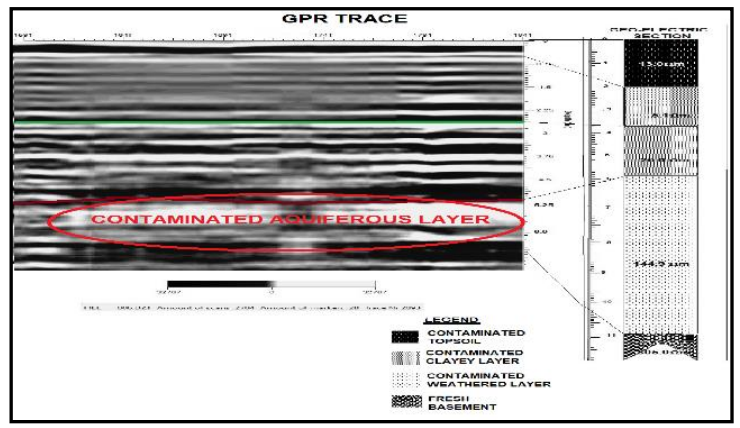

Fig 4: Geo-section - GPR trace through VES 2

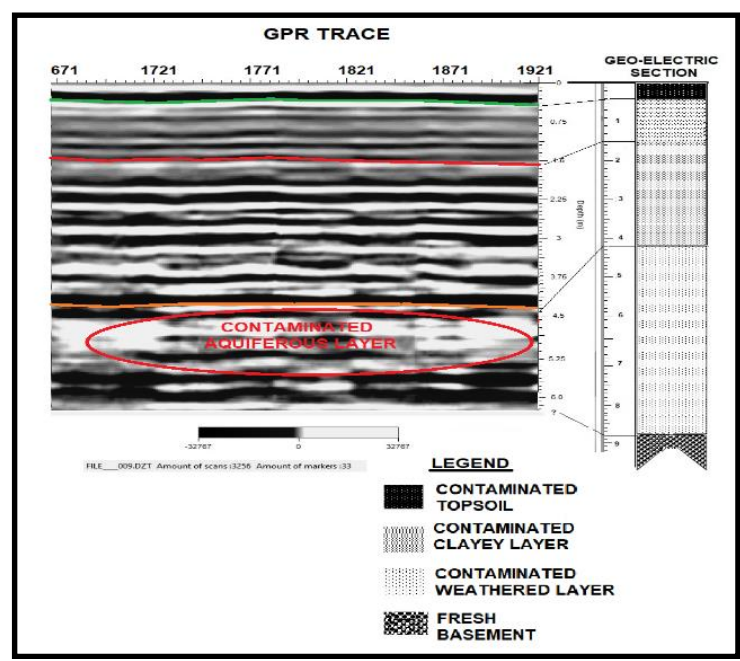

Fig 6: Geo-section - GPR trace through VES 4

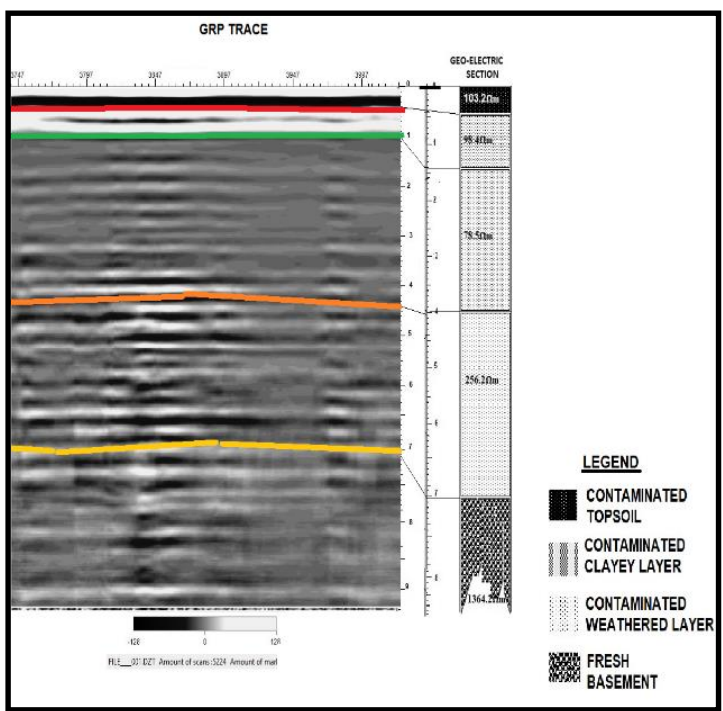

Fig 7: Geo-section - GPR trace through VES 5 (Control) 
Table 3. Summary Table of All VES Field Data Interpretation in the Study Area

\begin{tabular}{|c|c|c|c|c|c|}
\hline SN & Curve Type & $\begin{array}{l}\text { Resistivity } \\
(\Omega \mathrm{m})\end{array}$ & $\begin{array}{l}\text { Thickness } \\
(\mathrm{m})\end{array}$ & $\begin{array}{l}\text { Depth } \\
(\mathrm{m})\end{array}$ & Lithology \\
\hline \multirow[t]{5}{*}{ VES 1} & KHA & 18.5 & 0.48 & 0.48 & Contaminated Topsoil \\
\hline & & 90.2 & 1.19 & 1.67 & Contaminated Clayey layer \\
\hline & & 10.1 & 3.22 & 4.89 & Contaminated clayey layer \\
\hline & & 145.8 & 4.54 & 9.43 & Weathered layer \\
\hline & & 1363.6 & - & - & Fresh basement \\
\hline \multirow[t]{5}{*}{ VES 2} & HA.A & 13.0 & 2.07 & 2.07 & Contaminated Topsoil \\
\hline & & 5.16 & 1.68 & 3.75 & Contaminated Clayey layer \\
\hline & & 20.0 & 2.15 & 5.90 & Contaminated clayey layer \\
\hline & & 144.9 & 5.06 & 10.96 & Weathered layer \\
\hline & & 805.6 & - & - & Fresh basement \\
\hline \multirow[t]{5}{*}{ VES 3} & KHA & 7.59 & 0.41 & 0.41 & Contaminated Topsoil \\
\hline & & 40.7 & 1.07 & 1.48 & Contaminated Clayey layer \\
\hline & & 7.12 & 2.65 & 4.13 & Contaminated clayey layer \\
\hline & & 148.7 & 4.59 & 8.72 & Weathered layer \\
\hline & & 1114.7 & - & - & Fresh basement \\
\hline \multirow[t]{5}{*}{ VES 4} & $\mathrm{KHA}$ & 7.78 & 0.42 & 0.42 & Contaminated Topsoil \\
\hline & & 38.4 & 1.13 & 1.54 & Contaminated Clayey layer \\
\hline & & 8.88 & 2.63 & 4.18 & Contaminated clayey layer \\
\hline & & 182 & 4.62 & 8.80 & Weathered layer \\
\hline & & 1271.2 & - & - & Fresh basement \\
\hline \multirow[t]{5}{*}{ VES 5} & QHA & 103.2 & 0.42 & 0.42 & Topsoil \\
\hline & (Control) & 98.4 & 0.99 & 1.41 & Clayey sand layer \\
\hline & & 78.5 & 2.60 & 4.01 & clayey layer \\
\hline & & 256.2 & 3.03 & 7.04 & Weathered layer \\
\hline & & 1364.2 & & & Fresh basement \\
\hline
\end{tabular}

The acquiferous layers in the study area was found to be located at an average depth of about $4.13 \mathrm{~m}$ to 5.9 $\mathrm{m}$ which correspond to the depth to most of the surface wells in the study area. The resistivity of the aquiferous layer was found to be very low and range in value from as low as $5.1 \Omega \mathrm{m}$ in VES 2 to as high as $40 \Omega \mathrm{m}$ in VES 3. From the study, it is evident that the leachate from the dumpsite has migrated into the acquiferous layer in the study area and this has been responsible for the observed change in taste and odors of the groundwater in the study area. Geophysical survey via VES sounding and subsurface study by coring revealed that the top soil is made up of a thin lateritic material underlain with a clayey sand/sandy clay soil. This has been subjected to extensive pollution from the leachate of materials that percolates into the subsurface. For the leachate to have moved this far into the subsurface, there must could have been evidences of secondary porosity brought about, probably due to the use of heavy-duty lorries to convey the wastes into the dumpsite. This, coupled with the characteristic loose and nearly loose clayey sand underneath the fractured lateritic layer seem to explain why the dumpsite have experienced a quick failure and consequent abandonment. Table 2 shows the percentage of contribution of Cation/Anion /Heavy metals into the Pollution of the Groundwater

Conclusion: Electrical resistivity method and electromagnetic GPR method in the detection of subsurface contaminant at the study area seems to yield viable results as results obtained from the two geophysical techniques employed correlated well. The results obtained shows that the average depth to the contaminant is about $3.0 \mathrm{~m}$ to $4.0 \mathrm{~m}$ - the average depth to the aquifer in the study area. The study showed both the soil in the dumpsite as well as groundwater within the acquiferous layer has experienced contamination, due to low resistivity value, hence the need for closure.

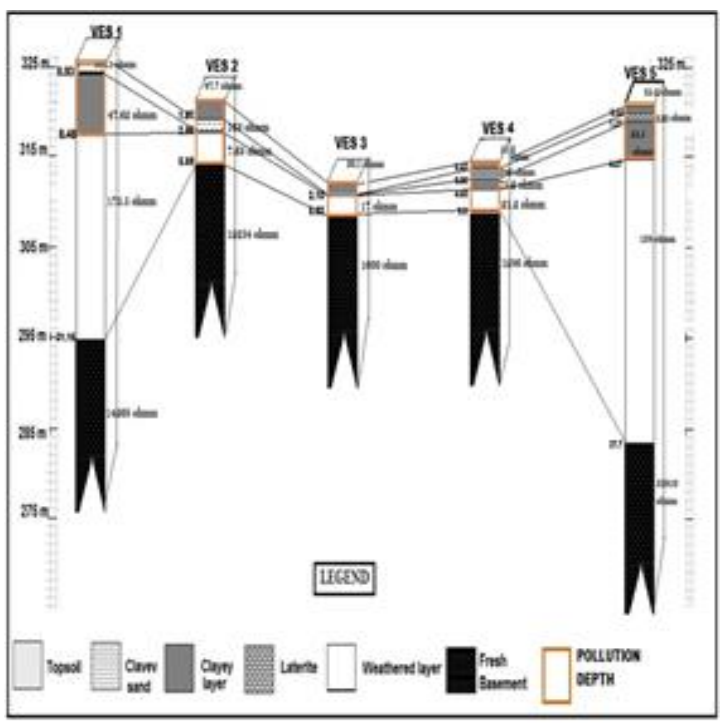

Fig 8: Geo-electric section of the study Area showing the VES points relative to elevation

Acknowledgement: This research has been carried out with the support of final year students of the Department of Geological Sciences, Osun State University, Osogbo. The authors wish to appreciate all the students that take part in the research work. Our immense appreciation goes to 
Mr. Afolabi Desire of the University of Ibadan who assisted in generating the map of the entire study area and also management of the Federal Ministry of Water Resources Laboratory, Akure for analysis of the water samples. Also, we will not forget in a hurry the immense contribution of all anonymous reviewers who reviewed this work. Then authors are grateful for these supports.

\section{REFERENCES}

Langer M., 1998, Geoenvironmental Aspects of Waste Disposal. Environ. Geology. 35. 1-2.

Lowrie W., 2007, Fundamentals of Geophysics. Cambridge University Press, UK, 383pp.

Ojo AO, Oyelami CA, Adereti AO (2014) Hydrogeochemical and Geophysical Study of Groundwater in the Suburb of Oshogbo, South Western Nigeria. J Earth Sci Clim Change 5: 205.

Olajire AA; Imeokparia FE (2001). Water quality assessment of Osun River: Studies on inorganic nutrients. Environ. Monitor. Assess. 69(1): 17-28

Olorunfemi MO; Meshida EA (1987) Engineering geophysics and its application in engineering site investigations (Case study from Ife-Ife area). The Nigerian Engineer 22:57-66
Oyelami AC; Ojo AO; Aladejana JA; Agbede OO (2013): Assessing the Effect of a Dumpsite on Groundwater Quality: A Case Study of Aduramigba Estate within Osogbo Metropolis; $J$. Environ. Earth, Vol. 3, No.1, 2013

Owamah, HI; Asiagwu AK; Egboh SHO; Phil-Usiayo S. (2013). Drinking Water Quality at Isoko North Communities of the Niger-Delta Region, Nigeria. Toxico. Environ. Chem. 95(7):1116-1128.

Prasad NB (1984). Hydrogeological studies in the Bhadra River Basin, Karnataka, India: University of Mysore, Ph.D thesis, p. 323

Shittu OB; Olaitan JO; Amusa TS (2009) Physicochemical and bacteriological analysis of water used for drinking and swimming in Abeokuta, Nigeria. Afr J Biomed Res 11:228-290

Udoessien, EI (2003). Basic principles of environmental science", Etiliew International Publishers, Uyo, Nigeria, $339 \mathrm{p}$

Ukpong EC; Okon BB (2013) Comparative Analysis of Public and Private Borehole Water Supply Source in Uruan Local government Area of Akwa Ibom State, Nigeria; Inter. J. of Appl. Scie. \& Tech.; 3 (1): 2013

Zume JT; Tahule A; Christenson S, (2006) subsurface Imaging of an abandoned Slid Waste landfill site in Norman, Oklahoma. Ground Water Monit. Remed. $26(2): 62-69$ 